\begin{abstract}
Iranica
Abstracta Iranica Revue bibliographique pour le domaine irano-aryen

Volume 37-38-39 | 2018

Comptes rendus des publications de 2014-2016
\end{abstract}

\title{
Ellen Rehm. „Kleinasiatische Gussformen aus der Perserzeit"
}

\section{Astrid Nunn}

\section{(2) OpenEdition \\ 12 Journals}

\section{Édition électronique}

URL : http://journals.openedition.org/abstractairanica/46178

DOI : 10.4000/abstractairanica.46178

ISBN : 1961-960X

ISSN : 1961-960X

Éditeur :

CNRS (UMR 7528 Mondes iraniens et indiens), Éditions de l'IFRI

Référence électronique

Astrid Nunn, «Ellen Rehm. „Kleinasiatische Gussformen aus der Perserzeit“ », Abstracta Iranica [En ligne], Volume 37-38-39 | 2018, document 71, mis en ligne le 30 décembre 2018, consulté le 02 octobre 2020. URL : http://journals.openedition.org/abstractairanica/46178 ; DOI : https://doi.org/ 10.4000/abstractairanica.46178

Ce document a été généré automatiquement le 2 octobre 2020.

Tous droits réservés 


\title{
Ellen Rehm. „Kleinasiatische Gussformen aus der Perserzeit“
}

\author{
Astrid Nunn
}

\section{RÉFÉRENCE}

Ellen Rehm. „Kleinasiatische Gussformen aus der Perserzeit“ in Holger Schwarzer, H.Helge Nieswandt (eds.). „Man kann es sich nicht prächtig genug vorstellen!“ Festschrift für Dieter Salzmann zum 65. Geburtstag. Marsberg/Padberg : Scriptorium, 2016, vol. II, p. $469-474$

1 Les moules en pierre existent en Mésopotamie depuis le $3^{\text {ème }}$ millénaire. Ils servaient de matrices principalement pour la production d'armes et de bijoux. Deux types de moules existaient ; à une valve ("Herdguss") ou bivalves ("Schalenguss") ce dernier n'étant jamais retrouvé lors de fouilles car une des valves est toujours perdue. L'A. s'attache dans cet article à huit poinçons et trois moules - dont deux à double valve - d'époque achéménide qui, malgré leur provenance du marché, offrent des informations intéressantes sur la réalisation technique de bijoux achéménides. Tous ces objets sont en bronze.

2 Les poinçons ont la forme d'une tête de lion et d'un sanglier. Ils servaient à donner une forme aux extrémités soit de bracelets soit de torques portées au cou. Leur style les rattache aux bijoux lydiens. Des moules, une matrice est en forme de tête de lion, une autre en forme de tête de lamassu, motif repris de l'iconographie assyrienne et répandu dans l'iconographie achéménide. La troisième matrice a la forme d'un griffon ailé. Ces objets indiquent une production locale de bijoux importante en Lydie achéménide. 


\section{AUTEURS}

\section{ASTRID NUNN}

Université de Munich 